\title{
Correction to: Social-ecological Systems of Latin America: Complexities and Challenges
}

\author{
Luisa E. Delgado and Víctor H. Marín
}

\section{Correction to:}

\section{E. Delgado, V. H. Marín (eds.), Social-ecological}

Systems of Latin America: Complexities and Challenges, https://doi.org/10.1007/978-3-030-28452-7

The following corrections are made to this Book:

The Acknowledgement section is added to Front Matter.

\section{Chapter 13:}

The name of the first author of the chapter entitled "San Rafael Reserve, Paraguay: Key Social Stakeholders and Sustainability Scenarios Through Environmental Governance Approaches" should be: Stella Mary Amarilla R.

The updated online version of this chapter can be found at https://doi.org/10.1007/978-3-030-28452-7_13

https://doi.org/10.1007/978-3-030-28452-7 